\title{
Comments on: Li et al. (2019) “Bioelectrochemical Systems for Groundwater Remediation: The Development Trend and Research Front Revealed by Bibliometric Analysis" Water, 11, 1532
}

\author{
Yuh-Shan Ho \\ Trend Research Centre, Asia University, No. 500, Lioufeng Road, Wufeng, Taichung 41354, Taiwan; \\ ysho@asia.edu.tw; Tel.: +886-4-2332-3456 (ext. 1797); Fax: +886-4-2330-5834
}

Received: 7 April 2020; Accepted: 30 May 2020; Published: 3 June 2020

Abstract: Li et al. (2019) used inappropriate searching words and method to publish a bibliometric paper in Water. The results show a huge difference from the results by using an appropriate method. This comment points out each of problems.

Keywords: bibliometric; searching words; SCI-EXPANDED; SSCI; front page; bioelectrochemical systems; groundwater remediation

Li et al. recently published a paper in Water entitled "Bioelectrochemical systems for groundwater remediation: The development trend and research front revealed by bibliometric analysis" [1]. Li et al. mentioned searching strategy in Section 2.1. Data Description as follows:

Indexes: SCI-EXPANDED and SSCI

Topic: (groundwater OR aquifer) AND (bioelectrochem* OR bio-electrochem* OR BES OR bioelectro* OR microbial electro* OR biolo* electro* OR bioelect* OR microbial fuel cell OR biogeobattery)

Timespan: 1999-2018

Language: English

Searching words are inappropriate, for example 511 documents can be found by (groundwater OR aquifer) and (biolo* electro*). Only two documents included "biological electron" in their author keywords. In fact, authors used not "biolo* electro*" but biolo* and electro* to search documents from the database [2,3]. Similarly, (microbial electro*) and (microbial fuel cell) mean (microbial and electro*) and (microbial and fuel and cell) but not "microbial electro*" and "microbial fuel cell". In addition, a total of 195 documents searched by (groundwater OR aquifer) AND (BES) without "BES" in the documents but, for example aerobes, anaerobes, besides, best, cubes, describes, microbes, Microtubes, nanotubes, probes, and tubes. Using (groundwater OR aquifer) AND (BES) are not the same as (groundwater OR aquifer) AND ("BES").

The Science Citation Index Expanded (SCI-EXPANDED) and Social Science Citation Index (SSCI) were originally designed not for bibliometric studies, but for researchers to find published literature $[3,4]$. It has been pointed out that it is necessary to have pre-treating data but not use the original data directly from SCI-EXPANDED and SSCI [5-7]. In order to improve the bias of using the SCI-EXPANDED and SSCI, the 'front page' (including the document title, the abstract, and the author keywords) as a filter has been proposed by Ho's group in 2012 [8].

Using the same method in the original paper [1] resulted in 1695 documents, including 1600 articles. A total of 1609 documents (95\% of the 1695 documents) without searching words in their 'front page', are not related to 'bioelectrochemical systems for groundwater remediation', for example the highly cited articles entitled "Electrode-reducing microorganisms that harvest 
energy from marine sediments" [9], "Microbial communities associated with electrodes harvesting electricity from a variety of aquatic sediments" [10], and "Anaerobic benzene oxidation coupled to nitrate reduction in pure culture by two strains of Dechloromonas" [11], as well as the highly cited reviews entitled "Dissimilatory Fe(III) and Mn(IV) reduction" [12] and "Microbial reduction of metals and radionuclides" [13]. Furthermore, the top articles in "Table 3. Summary of the top 10 cited publications of BESs for groundwater remediation during 1999-2018.' in the original paper [1] were not related to 'Bioelectrochemical systems for groundwater remediation'. Any of searching words such as "bioelectrochem", "bio-electrochem*", "BES", "bioelectro*", "microbial electro", "biolo* electro*", "bioelect*", "microbial fuel cell", and "biogeobattery" cannot be found in the 'front page' of the top ten most frequently cited articles, including 'Stimulating the in situ activity of Geobacter species to remove uranium from the groundwater of a uranium-contaminated aquifer' [14], 'Enrichment of members of the family Geobacteraceae associated with stimulation of dissimilatory metal reduction in uranium-contaminated aquifer sediments' [15], 'In situ bioreduction of technetium and uranium in a nitrate-contaminated aquifer' [16], 'Microbial communities associated with anaerobic benzene degradation in a petroleum-contaminated aquifer' [17], 'Pilot-scale in situ bioremedation of uranium in a highly contaminated aquifer. 2. Reduction of $\mathrm{U}(\mathrm{VI})$ and geochemical control of U(VI) bioavailability' [18], 'Change in bacterial community structure during in situ biostimulation of subsurface sediment cocontaminated with uranium and nitrate' [19], 'Microbiological and geochemical heterogeneity in an in situ uranium bioremediation field site ness' [20], Dissimilatory $\mathrm{Fe}(\mathrm{III})$ and $\mathrm{Mn}(\mathrm{IV})$ reduction' [12], 'QIIME allows analysis of high-throughput community sequencing data' [21], and 'Extracellular electron transfer via microbial nanowires' [22]. In addition, articles by Holmes et al. [15], Wu et al. [18], Vrionis et al. [20], Caporaso et al. (This is a letter.) [21], and Reguera et al. [22] cannot be found by the searching strategy in the original paper [1].

$\mathrm{Li}$ et al. published 'Bioelectrochemical systems for groundwater remediation: The development trend and research front revealed by bibliometric analysis' in Water using an inappropriate method [1]. This may result in misleading readers of the journal [4,23]. It has been pointed out that authors have the duty to use accurate methods in their publications, reviewers have the responsibility to point out the mistakes, and finally, journal editors have to pay more attention to such problems in articles that are being accepted for publication [24].

Funding: This research received no external funding.

Conflicts of Interest: The author declares no conflict of interest.

\section{References}

1. Li, W.; Chen, X.H.; Xie, L.S.; Liu, Z.; Xiong, X.Y. Bioelectrochemical systems for groundwater remediation: The development trend and research front revealed by bibliometric analysis. Water 2019, 11, 1532. [CrossRef]

2. Ho, Y.S. Rebuttal to: Qian, Law, \& Wei “knowledge mapping in travel website studies: A scientometric review", vol. 19, pp. 192-209. Scand. J. Hosp. Tour. 2019, 19, 433-435.

3. Ho, Y.S. Comments on "A Bibliometric Analysis of Research on Intangible Cultural Heritage Using CiteSpace" by Su et al. (2019). SAGE Open 2019, 9, 2158244019894291. [CrossRef]

4. Ho, Y.S. Comment on: "A Bibliometric Analysis and Visualization of Medical Big Data Research" Sustainability 2018, 10, 166. Sustainability 2018, 10, 4851. [CrossRef]

5. Ho, Y.S. Comments on "Mapping the scientific research on non-point source pollution: A bibliometric analysis" by Yang et al. (2017). Environ. Sci. Pollut. Res. 2018, 25, 30737-30738. [CrossRef] [PubMed]

6. Ho, Y.S. Rebuttal to Peng et al. (2019). “Characteristics and development trends of ecohydrology in lakes and reservoirs: Insights from bibliometrics". Ecohydrology, 12(3), UNSP e2080. Ecohydrology 2019, 12, e2111. [CrossRef]

7. Ho, Y.S. Rebuttal to: Ma et al. "Past, current, and future research on microalga-derived biodiesel: A critical review and bibliometric analysis", vol. 25, pp. 10596-10610. Environ. Sci. Pollut. Res. 2020, 27, 7742-7743. [CrossRef] 
8. Fu, H.Z.; Wang, M.H.; Ho, Y.S. The most frequently cited adsorption research articles in the Science Citation Index (Expanded). J. Colloid Interface Sci. 2012, 379, 148-156. [CrossRef]

9. Bond, D.R.; Holmes, D.E.; Tender, L.M.; Lovley, D.R. Electrode-reducing microorganisms that harvest energy from marine sediments. Science 2002, 295, 483-485. [CrossRef]

10. Holmes, D.E.; Bond, D.R.; O’Neill, R.A.; Reimers, C.E.; Tender, L.R.; Lovley, D.R. Microbial communities associated with electrodes harvesting electricity from a variety of aquatic sediments. Microb. Ecol. 2004, 48, 178-190. [CrossRef]

11. Coates, J.D.; Chakraborty, R.; Lack, J.G.; O'Connor, S.M.; Cole, K.A.; Bender, K.S.; Achenbach, L.A. Anaerobic benzene oxidation coupled to nitrate reduction in pure culture by two strains of Dechloromonas. Nature 2001, 411, 1039-1043. [CrossRef] [PubMed]

12. Lovley, D.R.; Holmes, D.E.; Nevin, K.P. Dissimilatory Fe(III) and Mn(IV) reduction. Adv. Microb. Physiol. 2004, 49, 219-286. [PubMed]

13. Lloyd, J.R. Microbial reduction of metals and radionuclides. FEMS Microbiol. Rev. 2003, 27, 411-425. [CrossRef]

14. Anderson, R.T.; Vrionis, H.A.; Ortiz-Bernad, I.; Resch, C.T.; Long, P.E.; Dayvault, R.; Karp, K.; Marutzky, S.; Metzler, D.R.; Peacock, A.; et al. Stimulating the in situ activity of Geobacter species to remove uranium from the groundwater of a uranium-contaminated aquifer. Appl. Environ. Microbiol. 2003, 69, 5884-5891. [CrossRef]

15. Holmes, D.E.; Finneran, K.T.; O'Neil, R.A.; Lovley, D.R. Enrichment of members of the family Geobacteraceae associated with stimulation of dissimilatory metal reduction in uranium-contaminated aquifer sediments. Appl. Environ. Microbiol. 2002, 68, 2300-2306. [CrossRef]

16. Istok, J.D.; Senko, J.M.; Krumholz, L.R.; Watson, D.; Bogle, M.A.; Peacock, A.; Chang, Y.J.; White, D.C. In situ bioreduction of technetium and uranium in a nitrate-contaminated aquifer. Environ. Sci. Technol. 2004, 38, 468-475. [CrossRef]

17. Rooney-Varga, J.N.; Anderson, R.T.; Fraga, J.L.; Ringelberg, D.; Lovley, D.R. Microbial communities associated with anaerobic benzene degradation in a petroleum-contaminated aquifer. Appl. Environ. Microbiol. 1999, 65, 3056-3063. [CrossRef] [PubMed]

18. Wu, W.M.; Carley, J.; Gentry, T.; Ginder-Vogel, M.A.; Fienen, M.; Mehlhorn, T.; Yan, H.; Caroll, S.; Pace, M.N.; Nyman, J.; et al. Pilot-scale in situ bioremedation of uranium in a highly contaminated aquifer. 2. Reduction of U(VI) and geochemical control of U(VI) bioavailability. Environ. Sci. Technol. 2006, 40, 3986-3995. [CrossRef] [PubMed]

19. North, N.N.; Dollhopf, S.L.; Petrie, L.; Istok, J.D.; Balkwill, D.L.; Kostka, J.E. Change in bacterial community structure during in situ Biostimulation of subsurface sediment cocontaminated with uranium and nitrate. Appl. Environ. Microbiol. 2004, 70, 4911-4920. [CrossRef]

20. Vrionis, H.A.; Anderson, R.T.; Ortiz-Bernad, I.; O’Neill, K.R.; Resch, C.T.; Peacock, A.D.; Dayvault, R.; White, D.C.; Long, P.E.; Lovley, D.R. Microbiological and geochemical heterogeneity in an in situ uranium bioremediation field site ness. Appl. Environ. Microbiol. 2005, 71, 6308-6318. [CrossRef]

21. Caporaso, J.G.; Kuczynski, J.; Stombaugh, J.; Bittinger, K.; Bushman, F.D.; Costello, E.K.; Fierer, N.; Pena, A.G.; Goodrich, J.K.; Gordon, J.I.; et al. QIIME allows analysis of high-throughput community sequencing data. Nat. Methods 2010, 7, 335-336. [CrossRef] [PubMed]

22. Reguera, G.; McCarthy, K.D.; Mehta, T.; Nicoll, J.S.; Tuominen, M.T.; Lovley, D.R. Extracellular electron transfer via microbial nanowires. Nature 2005, 435, 1098-1101. [CrossRef] [PubMed]

23. Ho, Y.S. Comment on Chen, J.; Su, Y.; Si, H.; Chen, J. Managerial Areas of Construction and Demolition Waste: A Scientometric Review. Int. J. Environ. Res. Public Health 2018, 15, 2350. Int. J. Environ. Res. Public Health 2019, 16, 1837. [CrossRef] [PubMed]

24. Ho, Y.S. Some comments on using of Web of Science for bibliometric studies [Environ. Sci. Pollut. Res. Vol. 25]. Environ. Sci. Pollut. Res. 2020, 27, 6711-6713. [CrossRef] [PubMed]

(C) 2020 by the author. Licensee MDPI, Basel, Switzerland. This article is an open access article distributed under the terms and conditions of the Creative Commons Attribution (CC BY) license (http://creativecommons.org/licenses/by/4.0/). 